\title{
Awareness on Prevention and First Aid Management of Burn Injury among Adolescents
}

\author{
Sarita Shrestha, ${ }^{1}$ Pramila Gurung ${ }^{2}$ \\ ${ }^{1}$ Nepalese Army Institute of Health Sciences-College of Nursing, Kathmandu, ${ }^{2}$ Shree Birendra Hospital, Kathmandu, \\ Nepal.
}

\begin{abstract}
Background: Burn means more than the burning sensation associated with injury. Burns are characterized by severe skin damage that causes the affected skin cells to die. Burns are causes for mortality and morbidity worldwide among all age groups. An estimated 180000 deaths every year are caused by burns - the vast majority occur in low- and middle-income countries. ${ }^{1}$ Non-fatal burn injuries are a leading cause of morbidity. Burns occur mainly in the home and workplace. Burns are preventable. Burns are one of the most common household injuries, especially among children. Most people can recover from burns without serious health consequences, depending on the cause and degree of injury. More serious burns require immediate emergency medical care to prevent complications and death. The objective of the study was to find out the awareness on prevention and first aid management of burn injury among adolescents. Materials and Methods: A descriptive exploratory study was conducted, using self administered questionnaire. Data was collected from 101 students of class VIII and IX of Shree Prithvi Narayan Secondary School at Tarkeshwor ward no. 5, Kathmandu. Descriptive statistics such as frequency, percentage and mean was used to analyze the data. Level of awareness was categorized as: $\angle 50 \%=$ Inadequate awareness, $50 \%-75 \%=$ Moderate awareness and $>75 \%=$ Adequate level of awareness. Results: In this study, respondents were between $12-16$ years of age with mean age 14.20 years. Among them $54.5 \%$ were female and $45.5 \%$ were male. Regarding level of burn injury prevention awareness $15.8 \%$ of the respondents had inadequate, $40.6 \%$ had moderate and $43.6 \%$ had adequate awareness. Likewise, $4.9 \%$ of the respondents had inadequate awareness, $71.3 \%$ had moderate awareness and $23.8 \%$ had adequate awareness on first aid management of burn injury.
\end{abstract}

Keywords: adolescents; awareness; burn injury; first aid management; prevention.

\section{INTRODUCTION}

A burn is an injury to the skin or other organic tissue primarily caused by heat or due to radiation, radioactivity, electricity, friction or contact with chemicals. Skin injuries due to ultraviolet radiation, radioactivity, electricity or chemicals, as well as respiratory damage resulting from smoke inhalation, are also considered to be burns.1 Overall, nearly $60 \%$ of fatal burns occur in Southeast Asia with a rate of 11.6 per 100,000.2 Burns are a global public health problem. An estimated 265000 deaths occur each year from fires alone, with more deaths from scalds, electrical burns, and other forms of burns, for which global data are not available. Over $96 \%$ of fatal fire-related burns occur in low- and middleincome countries. In many high-income countries, burn death rates have been decreasing, and the rate of child deaths from burns is currently over 7 times higher in low- and middle-income countries than in high-income countries. Non-fatal burns are a leading cause of morbidity, including prolonged hospitalization, disfigurement and disability, often with resulting stigma and rejection.1 The highest incidence of fire burns occurs in those 18-35 years old, while the highest incidence of scalds occurs in children less than five years old and adults over 65.3

About $90 \%$ of burns occur in the developing world. This has been attributed partly to overcrowding and an unsafe cooking situation. In the developed world, adult males have twice the mortality as females from burns. This is most probably due to their higher risk occupations and greater risk-taking activities. In many countries in the developing world, however, females have twice the risk of males. This is often related to accidents in the kitchen or domestic violence. In children, deaths from burns occur at more than ten times the rate in the developing than

Correspondence: Sarita Shrestha, Nepalese Army Institute of Health Sciences-College of Nursing, Kathmandu, Nepal. Email: sakulstha@gmail.com. Phone: +977-9841270208. DOI: 10.3126/ jcmsn.v14i4.21330. Article received: 2018-10-11. Article accepted: 2018-12-10. 
the developed world.4 School age and adolescence children start to engage in risk-taking behavior whereas domestic environment especially modern home is becoming more and more sources of risk, both as a result of technological progress (electricity, gas, etc). In addition to this, parents are nowadays more often away from home and have little time to look after their children so they are more vulnerable to burn injury. 5

Death due to burn occurs mostly in adolescents and early adulthood. Among pediatric injuries, the majority of the injury burden appears to be among younger children, particularly below the age of 5 years. 6 In India, about 700,000 to 800,000 people per year sustain significant burns, though very few are looked after in specialist burn units. The highest rates occur in women 16-35 years of age. Part of this high rate is related to unsafe kitchens and loosefitting clothing typical to India.7 Burns in children result in the loss of precious life, or if the child survives, in much suffering from physical, emotional social and economic problems .Thus, Education and awareness can contribute to prevent environmental hazard by guiding adolescents in school.

\section{MATERIALS AND METHODS}

Descriptive exploratory design was used to identify the awareness on prevention and first aid management of burn injury. The study was conducted at Shree Prithvi Narayan Secondary School at Tarkeshwor ward no.5, Kathmandu. All (107) students of class VIII \& IX were the study respondents. Those students who were absent during data collection period were excluded. Total 101 students data were collected, among them 40 students were from class VIII and 61 students were from class IX. Census method was used for the research study.

Informed written consent was obtained from all participants. The data was collected by using selfadministered questionnaires in class room settings. Participants was clearly instructed how to fill the questionnaires properly. To prevent contamination, researcher herself was present during data collection. Anonymity was maintained without ascribing name or identifiable personnel description. Field editing was done at the spot for any gap and completeness after the completion by respondents. Respondents were not forced to participate in the study. After the data collection, data was edited and coded. Coded data was entered, cleaned and analysed using Statistical Package for Social Science (SPSS) version 20. Data was presented based on objectives and variables by using descriptive statistical method such as frequency, mean, percentage.

\section{RESULTS}

The age of respondents ranged from 12 to 16 years, $36.6 \%$ of the respondent's age was $14 \mathrm{yrs}$ where as $23.8 \%$ of the respondent's age were 13 and 15 years respectively. Least 3\% respondent's age were 12years. Majority $(54.5 \%)$ of the respondents were female. More than Half (52.5\%) of the respondents were Brahmin \& Chhetri. Similarly, Most (78.2\%) of respondents were from Hindu religion. Table 1 reveals that regarding the meaning of burn injury almost all (91.1\%) respondents answered burn injury as skin injury due to fire. Almost all $(90.1 \%)$ of respondents said fire as causes of burn injury. likewise, most $(82.2 \%)$ of respondents equally mentioned information of prevention and first aid management of burn injury get from television and books.

\begin{tabular}{|c|c|c|}
\hline Variables & Frequency & Percent \\
\hline \multicolumn{3}{|l|}{ Meaning of burn * } \\
\hline $\begin{array}{l}\text { Injury to the skin due to } \\
\text { hot liquid }\end{array}$ & 77 & 76.2 \\
\hline $\begin{array}{l}\text { Injury to the skin due to } \\
\text { chemicals }\end{array}$ & 71 & 70.3 \\
\hline $\begin{array}{l}\text { Injury to the skin due to } \\
\text { electricity }\end{array}$ & 51 & 50.5 \\
\hline $\begin{array}{l}\text { Injury to the skin due to } \\
\text { fire }\end{array}$ & 92 & 91.1 \\
\hline \multicolumn{3}{|l|}{ Causes of Burn* } \\
\hline Smoking & 21 & 20.8 \\
\hline Hot liquid & 79 & 78.2 \\
\hline Chemicals & 73 & 72.3 \\
\hline Electricity & 52 & 51.5 \\
\hline Fire & 91 & 90.1 \\
\hline \multicolumn{3}{|l|}{ Sources of information* } \\
\hline Television & 82 & 82.2 \\
\hline Radio & 60 & 59.4 \\
\hline Newspaper & 55 & 54.5 \\
\hline Book & 83 & 82.2 \\
\hline Family & 71 & 70.3 \\
\hline Friends & 52 & 51.5 \\
\hline Health personnel & 62 & 61.4 \\
\hline
\end{tabular}

* Multiple responses

Table 2 presents that nearly three fourth (74.3\%) of the respondents equally thought not keeping chemicals at home and chemicals kept out of children's reach as safety measures for chemical burn. almost all (90\%) all (90.1\%) thought keeping hot electrical appliances away as a safety measures of electrical burn injury. Similarly, most 
$(84.2 \%)$ of respondents said keeping gas regulator off is the safety measures of home burn injury. most $(88.1 \%)$ of respondents answered not allowing children to play near fire or stove for prevention of children from burn injury.

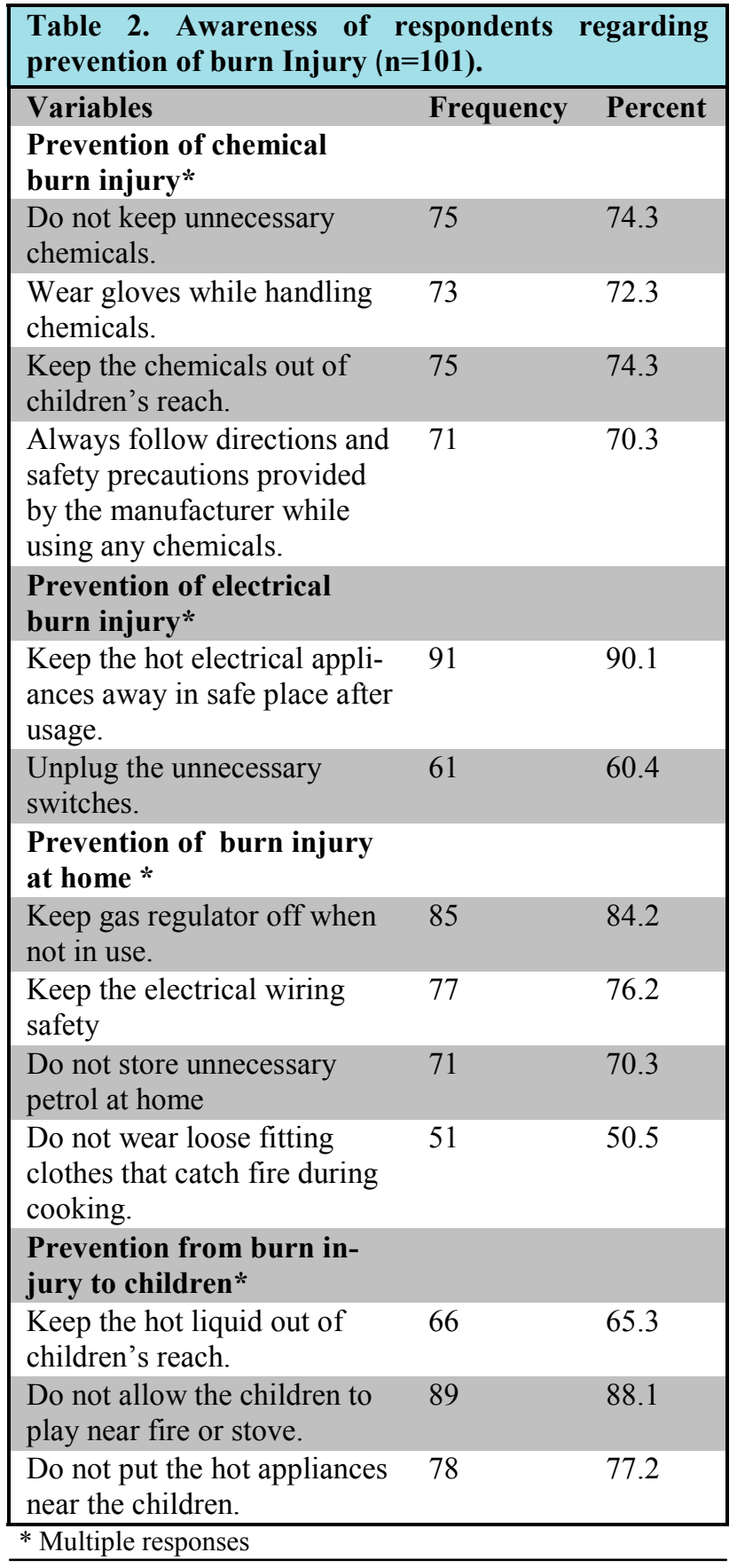

Table 3 shows that first aid management on injury the majority $(72.3 \%)$ of respondents said see their safety first. majority $(71.3 \%)$ of respondents answered cooling the burnt area with water for 1020 minutes after hot liquid burn. likewise, majority $(78.2 \%)$ of respondents responses washing the burnt area with water after chemical burn injury. Almost all (94.1\%) of respondents answered switching off the main switchbox for electrical burn injury. most of the respondents said transfer the victims to hospital as soon as possible.

Table 3. Awareness of respondents regarding first aid management of burn Injury $(n=101)$.

\begin{tabular}{|c|c|c|}
\hline Variables & Frequency & Percent \\
\hline \multicolumn{3}{|l|}{$\begin{array}{l}\text { First aid management when } \\
\text { a person catches fire* }\end{array}$} \\
\hline See your safety first. & 73 & 72.3 \\
\hline $\begin{array}{l}\text { Cover the person with blan- } \\
\text { ket. }\end{array}$ & 66 & 65.3 \\
\hline $\begin{array}{l}\text { Lay down the victim on } \\
\text { ground. }\end{array}$ & 38 & 37.6 \\
\hline $\begin{array}{l}\text { Pour the water on victim's } \\
\text { body }\end{array}$ & 37 & 36.6 \\
\hline $\begin{array}{l}\text { Transfer to the hospital as } \\
\text { soon as possible. }\end{array}$ & 89 & 88.1 \\
\hline \multicolumn{3}{|l|}{$\begin{array}{l}\text { First aid management of } \\
\text { burn from hot liquid* }\end{array}$} \\
\hline $\begin{array}{l}\text { Cool the burnt area with wa- } \\
\text { ter for } 10-20 \text { minutes. }\end{array}$ & 72 & 71.3 \\
\hline $\begin{array}{l}\text { Apply aloevera or other } \\
\text { herbs. }\end{array}$ & 68 & 67.3 \\
\hline \multicolumn{3}{|l|}{$\begin{array}{l}\text { First aid management of } \\
\text { chemical burn injury* }\end{array}$} \\
\hline $\begin{array}{l}\text { Wash the area with clean } \\
\text { water only. }\end{array}$ & 79 & 78.2 \\
\hline $\begin{array}{l}\text { Rinse the burn area immedi- } \\
\text { ately for } 10 \text { or more minutes. }\end{array}$ & 25 & 24.8 \\
\hline $\begin{array}{l}\text { Remove contaminated cloth- } \\
\text { ings or jewellery. }\end{array}$ & 37 & 36.6 \\
\hline \multicolumn{3}{|l|}{$\begin{array}{l}\text { First aid management of } \\
\text { chemical burn injury in } \\
\text { eye* }\end{array}$} \\
\hline $\begin{array}{l}\text { Hold affected side under run- } \\
\text { ning water. }\end{array}$ & 34 & 33.7 \\
\hline $\begin{array}{l}\text { Check both eye lid for any } \\
\text { injury. }\end{array}$ & 66 & 65.3 \\
\hline $\begin{array}{l}\text { Shift the victim to the hospi- } \\
\text { tal. }\end{array}$ & 95 & 94.1 \\
\hline \multicolumn{3}{|l|}{$\begin{array}{l}\text { First aid management of } \\
\text { electrical burn injury* }\end{array}$} \\
\hline $\begin{array}{l}\text { Switch off the main switch } \\
\text { box. }\end{array}$ & 95 & 94.1 \\
\hline $\begin{array}{l}\text { Separate the person from } \\
\text { electrical sources by dry } \\
\text { wooden board. }\end{array}$ & 66 & 65.3 \\
\hline Check the injured area. & 57 & 56.4 \\
\hline $\begin{array}{l}\text { Refer to the hospital as soon } \\
\text { as possible. }\end{array}$ & 82 & 81.2 \\
\hline
\end{tabular}

Table 4 revealed that most $(85.1 \%)$ of respondents answered not breaking the blister when formed after burn injury. Likewise, most (84.2\%) of respondents said keeping the burn area clean if minor injury formed. Almost all (90.1\%) of the respondents said referring to the hospital if deep wound formed. 


\begin{tabular}{|l|l|l|}
\hline \multicolumn{3}{|l|}{ Table 4. Awareness of Respondents regarding First } \\
Aid Management on Types of Burn Injury (n=101). \\
\hline Variables & Frequency & Percent \\
\hline $\begin{array}{l}\text { First aid management } \\
\text { when blister form by } \\
\text { burn* }\end{array}$ & & \\
\hline Do not break the blister. & 86 & 85.1 \\
\hline $\begin{array}{l}\text { Put ointment on the affected } \\
\text { area. }\end{array}$ & 57 & 56.4 \\
\hline $\begin{array}{l}\text { Cover the blister area with } \\
\text { clean cloth. }\end{array}$ & 55 & 54.5 \\
\hline $\begin{array}{l}\text { First Aid Management } \\
\text { when minor wound occur } \\
\text { by burn* }\end{array}$ & & 84.2 \\
\hline Keep the burnt area clean. & 85 & 48.5 \\
\hline $\begin{array}{l}\text { Put ointment on the burnt } \\
\text { area. }\end{array}$ & 49 & 78.2 \\
\hline Consult the doctor & 79 & 90.1 \\
\hline $\begin{array}{l}\text { First Aid Management } \\
\text { when deep wound occur by } \\
\text { burn* }\end{array}$ & & \\
\hline Keep the burnt area clean. & 82 & \\
\hline $\begin{array}{l}\text { Cover the burnt area with } \\
\text { clean cloth. }\end{array}$ & 46 & \\
\hline Refer to the hospital. & 91 & \\
\hline * Multiple responses & & \\
\hline
\end{tabular}

The mean score of total awareness on prevention of burn injury was $17.47(72.8 \%)$ and the mean score of total awareness on first aid management of burn injury was $24.95(67.43 \%)$

\begin{tabular}{|c|c|c|}
\hline Variables & Frequency & Percent \\
\hline \multicolumn{3}{|c|}{$\begin{array}{l}\text { Awareness level on Pre- } \\
\text { vention }\end{array}$} \\
\hline Inadequate $(<50 \%)$ & 16 & 15.8 \\
\hline Moderate $(50 \%-75 \%)$ & 41 & 40.6 \\
\hline Adequate $(>75 \%)$ & 44 & 43.6 \\
\hline \multicolumn{3}{|c|}{$\begin{array}{l}\text { Awareness level on First } \\
\text { Aid Management }\end{array}$} \\
\hline Inadequate $(<50 \%)$ & 5 & 4.9 \\
\hline Moderate $(50 \%-75 \%)$ & 72 & 71.3 \\
\hline Adequate $(>75 \%)$ & 24 & 23.8 \\
\hline
\end{tabular}

\section{DISCUSSION}

Findings of the study showed that the age of respondents ranged from 12 to 16 years with mean age as 14.20 years. More than half of respondents were in the age of 14years and below, which indicated that majority of the participants were younger age. Regarding meaning of burn almost all $(91.1 \%)$ of respondents answered burn injury as skin injury due to fire. Almost all (90.1\%) of respondents answered fire as causes of burn injury, where as only $20.8 \%$ of respondents response smoking as cause of fire. In Nepal most of the fire was caused by negligence due to fire and electricity. Likewise, most (82.2\%) of respondents equally mentioned information obtained from television and books as source of information about first aid management of burn injury. The result of this study showed that a highest proportion of students were getting burn prevention and first aid knowledge from their school book. This emphasizing the school based knowledge is the best sources for children in preventing accidental burn and adoption of immediate first aid. This finding is contrast with study done in Zaria where nearly half $(43.2 \%)$ of students get information from school where as $(20 \%)$ family members, $(7.46 \%)$ television and $(6.57 \%)$ radio. $^{8}$

Regarding the prevention of burn injury, It was found that nearly three fourth (74.3\%)of respondents equally thought not keeping unnecessary chemicals at home and chemicals out of children's reach as safety measures for chemical burn. Most (84.2\%) of respondents answered keeping gas regulator off is the safety measures of home burn injury whereas majority $(70.3 \%)$ of the respondents answered not storing petrol at home as prevention for burn. Company provides old and damage cylinder to customer so that government should monitor timely for quality of gas cylinder for safety precaution. Most (88.1\%) of respondents answered not allowing children to play near fire or stove for prevention of children from burn injury. Majority (65.3\%) answered keeping the hot liquid out of children's reach. children are more vulnerable by hot liquid burns occur when a child pulls down a container of hot fluid, such as a hot water, cup of tea and coffee, onto his or her face, upper extremities and trunk. This finding was contrast with study done in Cambodia (16\%) of respondents responded with not playing with fire, (12\%) being careful with fire, and $(11 \%)$ staying away from fire, candles, kerosene lamps, and other hazardous objects. only 8\% responses keeping things away from fires (e.g. mosquito net, clothes, gasoline, similarly not burning things, and putting out fires after use (e.g. stove, kerosene lamp, candle). ${ }^{9}$ This study findings indicate that most of the respondents were aware on prevention of burn injury.

While analyzing the finding regarding awareness on first aid management of burn injury, majority $(65.3 \%)$ of the respondents said cover the person 
with blanket and $37.6 \%$ of respondents responses lay down the victim on ground. This finding is contrast with study done in Bangladesh were $(80.7 \%)$ of the respondents state stop, drop and roll when your clothes catch fire. ${ }^{10}$

Majority (71.3\%) of respondents answered cooling the burnt area with water for 10-20 minutes as first aid management of burn from hot liquid. $36.6 \%$ of the respondents said remove contaminated clothing or jewellery after burn. It is nearly coherent with a study done in New South Wales where $82 \%$ reported that they would cool a burn with water, and $9 \%$ reported that they would cool the burn for the recommended 20 minutes. Few respondents reported that they would remove the patient's clothing and keep the injured person warm. ${ }^{11}$

Majority (67.3\%) of the respondents answered applying aloevera or other herbs as first aid management for hot liquid burn which is supported by the study done in Saudi adults where majority (69.9\%) of the respondents answered honey and half of the respondents $(53.7 \%)$ of the respondents answered toothpaste for first aid management of burn respectively. ${ }^{12}$ Traditional treatments, though, continue to be practiced. These include putting butter or oil on sunburn, and ice, aloe, sugar water, toothpaste or other household products on a second -degree burn. All these traditional practices can be harmful, as they can cause the skin to slough away, leaving the tender lower layers susceptible to infection. Although some agents such as honey or commercially available cold packs may indeed have some beneficial effects, they are better avoided. Instead, people should be advised to use only cool, clean water. ${ }^{13}$

Almost all (94.1\%) of respondents answered shifting the victim to hospital for the first aid management of chemical burn injury in eye. Chemical burn injury is common act of violence so government should make strict rule for sold and crime act. Awareness program on chemical burn injury among adolescent should be launched. Almost all (94.1\%) of respondents answered

\section{REFERENCES}

1. World Health Organization. 2018. http:// www.who.int/violence_injury_prevention/ other_injury/burns/en/ Archived from the original on 21 July 2018.

2. Herndon D. Chapter 3: Epidemiological, Demographic, and Outcome Characteristics of Burn Injury. Total burn care. 4th ed. switching off the main switchbox as first aid management for electrical burn injury. Most $(85.1 \%)$ of respondents answered not breaking the blister when formed after burn injury. Likewise, most $(84.2 \%)$ of respondents answered keeping the burn area clean if minor injury formed. Majority of the respondents' state that all types of burn victims should treated to hospital after first aid management. Study done in Bangladesh is nearly similar to all most all (94.0\%) of the respondents agreed with the statement that all burn injuries must be treated in the hospital.10 Finding of this study shows that respondents were aware on treatment of burn injury in hospital to prevent complications.

Regarding level of the knowledge of the respondents revealed that nearly one fourth $(23.8 \%)$ of the respondents had adequate awareness, majority (71.3\%) of the respondents had moderate awareness and least $(4.9 \%)$ had inadequate awareness on first aid management of burn injury.

\section{CONCLUSIONS}

Based on the findings and discussion of the study, it is concluded that nearly two fifth of respondents had adequate and moderate awareness on prevention of burn injury. Similarly, more than two-third of the respondents had moderate awareness and one fourth of respondents had adequate awareness regarding first aid management. Despite of adequate awareness on prevention of burn injury, respondents had lacked adequate awareness on first aid management of burn. It might be due to lack of awareness programme and insufficient burn first aid management in school curriculum. The use of the different means of education about the essential practices of burn first aid management can be further implemented in school subjects. Education may ultimately increase burn prevention if the message is repeated in the educational institute. School teacher should teach with more focus on burn prevention and first aid management as important subject matter in curriculum. Television could be used as a medium to teach children about burn safety. 
5. Atiyeh BS, Costagliola M, Hayek SN. Burn prevention mechanisms and outcomes: pitfalls, failures and successes. burns. 2009 Mar 1;35 (2):181-93.

6. Golshan A, Patel C, Hyder AA. A systematic review of the epidemiology of unintentional burn injuries in South Asia. Journal of public health. 2013 Jan 14;35 (3):384-96.

7. Ahuja RB, Bhattacharya S. ABC of burns: Burns in the developing world and burn disasters. BMJ: British Medical Journal. 2004 Aug 21;329 (7463):447.

8. Ibrahim A, Asuku ME, Dahiru T. Burn prevention and first aid knowledge: A focus on adolescents in Zaria. African Journal of Trauma. 2014 Jan 1;3 (1):11.

9. Hsiao M, Tsai B, Uk P, Jo H, Gomez M, Gollogly JG, Beveridge M. "What do kids know": a survey of 420 Grade 5 students in Cambodia on their knowledge of burn prevention and first-aid treatment. Burns. 2007
May 1;33 (3):347-51.

10. Arifuzzaman M, Muhammad F, Farahnaz S, Chowdury AR, Shahjahan M, Chowdhury AA. Burn prevention and first aid knowledge among high school students in Bangladesh. Daffodil International University Journal of Allied Health Sciences. 2016 January;3(1):41-49

11. Harvey LA, Barr ML, Poulos RG, Finch CF, Sherker S, Harvey JG. A population-based survey of knowledge of first aid for burns in New South Wales. Med J Aust. 2011 Oct 17;195 (8):465-8.

12. Kattan AE, AlShomer F, Alhujayri AK, Addar A, Aljerian A. Current knowledge of burn injury first aid practices and applied traditional remedies: a nationwide survey. Burns \& trauma. 2016 Dec;4(1):37.

13. Branche C, Oyebite K, Hyder AA, OzanneSmith J, Bartolomeos K, Rivara F. World report on child injury prevention. World Health Organization; 2008.

Citation: Shrestha S, Gurung P. Awareness on Prevention and First Aid Management of Burn Injury among Adolescents. JCMS Nepal. 2018;14(4):200-5. 